\title{
FINANCIAL MARKET INTEGRATION IN ASIA: EVIDENCE FROM STOCK AND BOND MARKET
}

\author{
Fauziah *)
}

\begin{abstract}
Financial integration especially in Asian financial market has been a defining feature of the world economy and has become a central issue in international finance for the past decades. However, there is limited empirical studies on the integration of Asian bond market. Therefore, this study aims to examine the financial market integration in Asia (Stock and Bond Market). The sample of this study is the major of Asian financial markets including Japan, China, Hong Kong, Singapore and South Korea during January 2009 - December 2016. Correlation, co-integration and causality tests used in this study to investigate the financial markets integrations. This study shows that both stock and bond returns are co-integrated and indicate as a common stochastic trends. Stock market integration appears to be much stronger compared to the less developed. This result is very important for investors to assess potential gains from portfolio diversification, and for a financial policymaker to manage market policies effectively and handle contagion risks that might be caused by international shock transmissions.
\end{abstract}

Keywords: Financial Market Integration, Stock Market, Bond Market

\section{INTRODUCTION}

\subsection{Research Background}

Financial integration has been a defining feature of the world economy (Belge and Keil, 2016) and has become a central issue in international finance in the past decades (Kim, Moshirian, $\mathrm{Wu}$; 2006). There is no common definition of financial integration, but at least contain two meaning i.e. integration of financial markets and free movement of capital (Chai \& Rhee, 2005). The financial market in the world increasingly integrated into line with the rapid development of information and communication technology, liberalization of cross-border capital flows, financial innovation and economic integration through international trade relations and the internationalization of production through Foreign Direct Investment (FDI) (Berben \& Jansen, 2005). Financial integration helps countries allocate resources efficiently and diversify their income risks across border (Yu, 2014).

There are much literatures that examines financial integration. Some studies focus on European financial integration (Kim, Moshirian, \& Wu, 2006; Berben \& Jansen, 2005; Buzelay, 2008; Deltuvaite, 2015), others focus on American financial integration (Pyun \& Jiyoun, 2016, Volosovych, 2011), Asian financial integration (Perera \& Wickramanayake, 2012; Rughoo \& You, 2015; Nguyen \& Elisabeta, 2016; Didier, Montanes, \& Schmukler, 2017), and other countries (Balcilar, Kutanc, \& Yay, 2017).

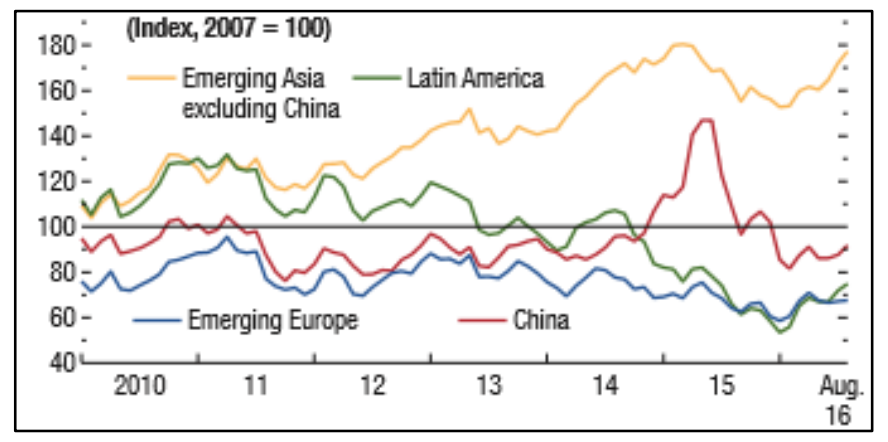

Picture 1 Stock Market Growth 
Asian financial market is one of the biggest financial markets in the world. Growing of Asian financial markets in the last decade very rapidly, both stock market or bond market. Even, on October 2016, International Monetary Fund (IMF) report that Asian stock market has been growing fastest in the world (International Monetary Fund World Economic Outlook, 2016). However, empirical studies on the integration of Asian bond market are very limited even though bond market have experienced drastic growth in recent years and it is an important part of the financial market integration process in Asia. Therefore, researcher are interested in examined here.

\subsection{Research Problem}

Based on the above reasoning, researcher need to evaluate how is the financial market integrationin Asia across two financial markets.

\subsection{Research Purpose}

The purpose of this research is to evaluate financial market integration in Asia across two financial markets i.e. stock market and bond market. The result of this research is very important for investors to assess potential gains from portfolio diversification, and for a financial policymaker to manage market policies effectively and handle contagion risks that might be caused by international shock transmissions

\section{THEORETICAL FRAMEWORK AND HYPOTHESES}

\subsection{Theoretical Framework}

\subsubsection{Financial Market Integration}

Financial markets are considered to be integrated when assets are priced by the same stochastic discount rate (Flood \& Rose, 2004). More precisely, in international financial markets, if the assets with identical risks offer similar level of expected returns, then markets are said to be integrated. Accordingly, if financial integration is complete, homogeneous assets should have the same price irrespective of the location of trading. This situation can be defined under the "law of one price". However, in reality, assets do not have sufficiently similar characteristics and hence, it is required to take into account differences in systematic risk factors and other important characteristics (Perera \& Wickramanayake, 2012). Moreover, although complete integration is not observed frequently, some form of integration can be observed across financial markets through several measures and indicators.

There exist three financial integration indicators, which can be used to measure the level of financial market integration i.e. price-based indicators, quantity-based indicators and regulatory and institutional measures (Perera \& Wickramanayake, 2012). Price-based indicator classified as direct measures of integration and also have a more clear-cut interpretation than others indicator (Kleimeier \& Sander, 2000). Hence, our study focused on this indicator that examine the comovement between asset prices (stock and bond).

The empirical work of financial integration has grown with proposed different measurement framework on price-based indicator among which Vector Auto-Regression (VAR) Model (Balcilar, Kutanc, \& Yay, 2016), which aim to investigate the effect of contagion, and cointegration and error-correction models (Perera \& Wickramanayake, 2012), which aim to assess the presence of long run equilibrium among cross-country financial variable. Our study combines this measurement framework.

\subsubsection{Research Hypotheses}

The hyphoteses in this study are:

$\mathrm{H}_{1}$ : There is a cointegration relationship (long-term balance) between the Stock market and Bond market in Asia.

$\mathrm{H}_{2}$ : There is financial market integration in all of sample country in Asia.

$\mathrm{H}_{3}$ : There is a causality relationship between the Stock market and Bond market in Asia 


\section{RESEARCH METHOD}

\subsection{Research Design}

In order to examine the empirical implications of financial integration, we use time-series data of stock market and bond market in Asia. The sample consists of five countries that have biggest financial market in Asia, namely: Japan, China, Hong Kong, Singapura, and South Korea. All of the data set in this study were retrieved from Data stream database.

Correlation, co-integration and causality tests, which are widely used methods in empirical applications, were used in this study to investigate the integration in financial markets, both stock and bond market. Under the co-integration analysis, the first step is to check if each series is integrated to the same order. This will be examined by employing the augmented Dickey-Fuller (ADF) test to determine if each series has a unit root. The second step entails testing for cointegration to check if the stock and bond markets share a common long-run trend. This will be investigated at a multivariate level using VAR model in Johansen Fisher Panel Cointegration Test. Finally, the causality among the market would be examined by the Pairwise Granger Causality Test (20). Granger causality tests help to deepen the understanding of integration between financial markets. All of the test running by Eviews 7.

\subsection{Population and Sample}

Researcher used weekly data of each market and each country in the form of the stock index return and the long-term (10 years) government bond yield, covers period on January 2009 December 2016.

\section{RESEARCH RESULT AND ANALYSIS}

The summary statistics of stock return and bond yield of all sample data displayed in below. As indicated in descriptive statistics of stock return presented in Picture 1, distributions of weekly stock returns of all sample countries have positive means $(0.158 \%)$. Stock return distributions of data sample shown negatively skewed distributions $(-0.171)$, which indicate a greater probability of high or positive returns compared to low/negative returns. The distribution of stock return report a kurtosis coefficient 4.918 , indicating leptokurtic distributions with many extreme observations. The zero p-values of Jarque-Bera test statistic indicate that the stock return distributions do not approximate the normal distributions for any country.
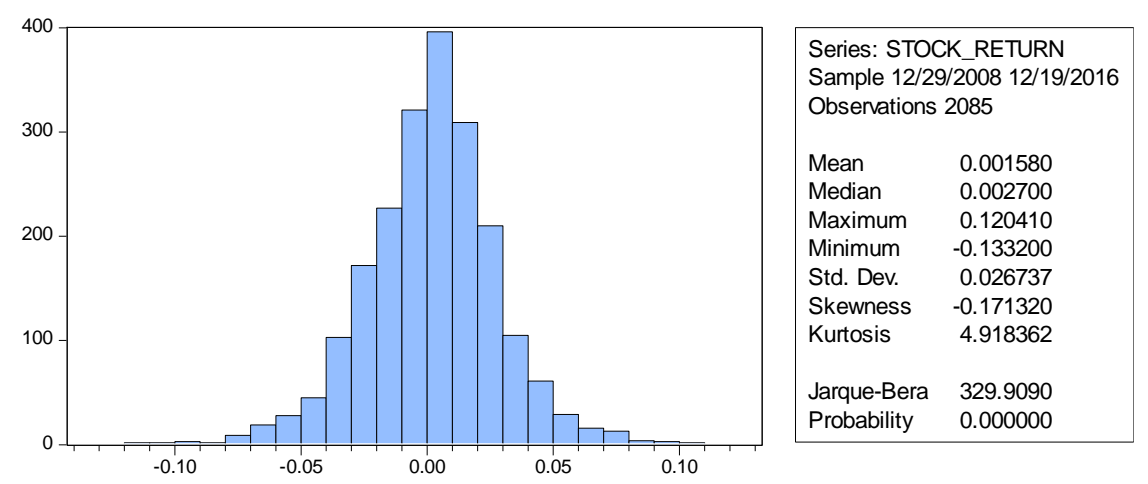

Picture 2 Descriptive Statistic of Stock Return 

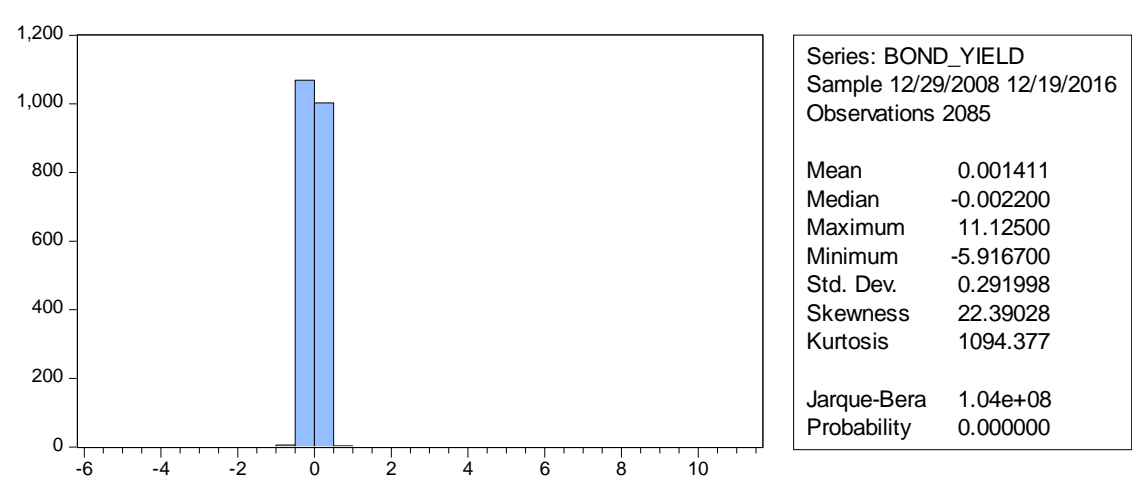

Picture 3 Descriptive Statistic of Bond Yield

According to descriptive statistics of bond yield presented in Picture 2 bond yield of five sample countries has positive means (0.141). Bond yield distribution is positively skewed (22.390), indicating the absence of high frequencies of higher returns (i.e. distributions are concentrated around low or negative returns). The zero p-values of Jarque-Bera test statistic of bond yield also indicate that the return distributions do not approximate the normal distributions.

Result of stock returns correlation between countries present in Table 1. This table shown that All of the stock return each country indicate strong correlations with stock return of other country (correlation coefficients are significant according to the probability values of the covariance analysis) except stock return of China index market. This result represents that stock market all of country sample in Asia is integrated except stock market of China. On the other hand, the result of bonds yield correlation between countries that are presented at Table 2 shows that a strong correlation occurs only among Japanese bond yields and Singapore bond yields.

Table 1 Results of Stock Returns Correlation Between Countries

\begin{tabular}{|l|l|l|l|l|l|}
\hline & SR_South Korea & SR_Singapore & SR_Japan & SR_Hong Kong SR_China \\
\hline SR_South Korea & 1.000000 & 0.559340 & 0.589328 & 0.700690 & 0.086276 \\
\hline SR_Singapore & 0.559340 & 1.000000 & 0.545346 & 0.650600 & 0.040092 \\
\hline SR_Japan & 0.589328 & 0.545346 & 1.000000 & 0.620081 & 0.085916 \\
\hline SR_Hong Kong & 0.700690 & 0.650600 & 0.620081 & 1.000000 & 0.117600 \\
\hline SR_China & 0.086276 & 0.040092 & 0.085916 & 0.117600 & 1.000000 \\
\hline
\end{tabular}

Note: SR is Stock Return

Table 2 Result of Yield Bond Correlation Between Countries

\begin{tabular}{|l|l|l|l|l|l|}
\hline & BY_South Korea & BY_Singapore & BY_Japan & BY_Hong Kong & BY_China \\
\hline BY_South Korea & 1.000000 & 0.384321 & -0.078954 & 0.459478 & 0.150462 \\
\hline BY_Singapore & 0.384321 & 1.000000 & -0.055218 & 0.566072 & 0.080761 \\
\hline BY_Japan & -0.078954 & -0.055218 & 1.000000 & -0.001118 & 0.010010 \\
\hline BY_Hong Kong & 0.459478 & 0.566072 & -0.001118 & 1.000000 & 0.102530 \\
\hline BY_China & 0.150462 & 0.080761 & 0.010010 & 0.102530 & 1.000000 \\
\hline
\end{tabular}

Note: BY is Bond Yield

Table 3 shows the results of ADF unit root test of stock return and bond yield. From ADFFisher Chi-square and ADF-Choi Z-stat probability, indicate that stock return and bond yield are stationary at zero order, significant at $1 \%$ level. It means that each series is integrated to the same order. At the same time, an unrestricted VAR was estimated to find the lag length, for which Schwaz information criteria (SIC) was used. SIC is minimized at level 6 and the residual serial correlation Lagrange multiplier (LM) test confirms that there is no autocorrelation. Therefore, lag 6 was selected as the optimal lag length. The result of Cointegration Test is presented on Table.4. Based on Johansen Fisher Panel Cointegration which testing with trace category statistic test and 
Maximum Eigenvalue Statistic test in Table 4, the probability value is 0.0000 . These results indicate that the null hypothesis, which is stated there is no cointegration relationship between Stock market and Bond market is rejected and accepted the alternative hypothesis as the probability value is less than $0.01(0.0000<0.01)$. These results prove that there is a cointegration relationship (long-term balance) between the Stock market and Bond market in Asia with significance level at $1 \%$. This means that there is a relationship of balance and similarity movement in the long term between the stock return and bond yield in Asia. Accordingly, these results convincingly suggest that stock and bond markets in the selected Asian countries are co-integrated. In other words, it indicates that common stochastic trend in these stock and bond markets. It seems that these markets share a long-run stable relationship and can be viewed as one asset market.

Table 3 Results of Augmented Dickey-Fuller (ADF) Unit Root Test

\begin{tabular}{|l|c|c|c|c|}
\hline \multirow{2}{*}{\multicolumn{1}{|c|}{ Method }} & \multicolumn{2}{|c|}{ Stock Return } & \multicolumn{2}{c|}{ Bond Yield } \\
\cline { 2 - 5 } & Statistic & Prob.** & Statistic & Prob.** \\
\hline ADF - Fisher Chi-square & 791.879 & 0.0000 & 636.136 & 0.0000 \\
\hline ADF - Choi Z-stat & -27.5229 & 0.0000 & -24.2278 & 0.0000 \\
\hline
\end{tabular}

Table 4 Results of Johansen Fisher Panel Cointegration Test

\begin{tabular}{|c|c|c|c|c|}
\hline Hypothesized & Fisher Stat.* & & Fisher Stat.* & \\
\hline No. of CE(s) & (from trace test) & Prob. & (from max-eigen test) & Prob. \\
\hline None & 92.10 & 0.0000 & 92.10 & 0.0000 \\
\hline At most 1 & 1317. & 0.0000 & 1317. & 0.0000 \\
\hline
\end{tabular}

Table 5 Results of Individual Cross Section of Cointegration Test

\begin{tabular}{|c|c|c|c|c|}
\hline \multirow{2}{*}{ Cross Section } & Trace Test & \multirow{2}{*}{ Prob.** } & Max-Eign Test & \multirow{2}{*}{ Prob.** } \\
\cline { 2 - 5 } & Statistics & & Statistics & \\
\hline Hypotheses of no cointegration & & \\
\hline JAPAN & 357.1143 & 0.0001 & 191.1775 & 0.0001 \\
\hline CHINA & 322.9758 & 0.0001 & 185.8828 & 0.0001 \\
\hline HONG KONG & 307.3720 & 0.0001 & 174.8463 & 0.0001 \\
\hline SINGAPORE & 302.9525 & 0.0001 & 166.8049 & 0.0001 \\
\hline SOUTH KOREA & 307.4879 & 0.0001 & 159.7499 & 0.0001 \\
\hline Hypotheses of at most 1 cointegration relationship & \\
\hline JAPAN & 165.9368 & 0.0000 & 165.9368 & 0.0000 \\
\hline CHINA & 137.0930 & 0.0000 & 137.0930 & 0.0000 \\
\hline HONG KONG & 132.5257 & 0.0000 & 132.5257 & 0.0000 \\
\hline SINGAPURA & 136.1476 & 0.0000 & 136.1476 & 0.0000 \\
\hline SOUTH KOREA & 147.7379 & 0.0000 & 147.7379 & 0.0000 \\
\hline
\end{tabular}

Table 5 present the result of individual cross section of Cointegration. Probability trace and Maximum Eigenvalue test statistic of Johansen Fisher Panel Cointegration Test all country is 0.0001 on hypothesis of no cointegration and 0.0000 on hypothesis of at most 1 cointegration relationship. This result indicates that there is financial market integration in all of sample country in Asia (Japan, China, Hong Kong, Singapore, and South Korea). Table 5. also shows that the null hypothesis which states stock return does not cause a change in the bond yield is also rejected and accept the alternative hypothesis. This proves that the stock return causes a change in the bond yield is significant at the $1 \%$ significance level. These results indicate that the variations that occur in the stock return will cause a variation in stock prices, and vice versa, variation that occurs in the bond yield will lead to variations in the stock return. If the bond yield decline, the more interested investors to invest in Asian stock markets and the Asian stock indexes will be increasing. 
Table 6 Results of Pairwise Granger Causality Tests

\begin{tabular}{|c|c|c|c|}
\hline Null Hypotheses: & Obs & F-Statistic & Prob. \\
\hline BOND YIELD does not Granger Cause STOCK RETURN & \multirow[t]{2}{*}{2055} & 1.82654 & $0.0902 *$ \\
\hline STOCK RETURN does not Granger Cause BOND_YIELD & & 5.06391 & $4 . \mathrm{E}-05 * *$ \\
\hline Null Hypotheses: & Obs & F-Statistic & Prob. \\
\hline SR_HONG_KONG does not Granger Cause SR_CHINA & 415 & 2.11813 & 0.1216 \\
\hline SR_CHINA does not Granger Cause SR_HONG_KONG & & 7.27665 & $0.0008 * * *$ \\
\hline SR_JAPAN does not Granger Cause SR_CHINA & 415 & 2.33580 & $0.0980 *$ \\
\hline SR_CHINA does not Granger Cause SR_JAPAN & & 1.57181 & 0.2089 \\
\hline SR_SINGAPORE does not Granger Cause SR_CHINA & 415 & 0.22432 & 0.7992 \\
\hline SR_CHINA does not Granger Cause SR_SINGAPORE & & 6.27814 & $0.0021 * * *$ \\
\hline SR_SOUTH_KOREA does not Granger Cause SR_CHINA & 415 & 1.02115 & 0.3611 \\
\hline SR_CHINA does not Granger Cause SR_SOUTH_KOREA & & 4.19256 & $0.0158 * *$ \\
\hline SR_JAPAN does not Granger Cause SR_HONG_KONG & 415 & 0.75099 & 0.4725 \\
\hline SR_HONG_KONG does not Granger Cause SR_JAPAN & & 0.09915 & 0.9056 \\
\hline SR_SINGAPORE does not Granger Cause $\quad$ SR_HONG_KONG & 415 & 2.50897 & $0.0826^{*}$ \\
\hline SR_HONG_KONG does not Granger Cause SR_SINGAPORE & & 0.97850 & 0.3768 \\
\hline SR_SOUTH_KOREA does not Granger Cause SR_HONG_KONG & 415 & 3.96932 & $0.0196 * *$ \\
\hline SR_HONG_KONG does not Granger Cause SR_SOUTH_KOREA & & 1.41677 & 0.2437 \\
\hline SR_SINGAPORE does not Granger Cause SR_JAPAN & 415 & 0.8 & 0.4193 \\
\hline SR_JAPAN does not Granger Cause SR_SINGAPORE & & 1.35939 & 0.2580 \\
\hline SR_SOUTH_KOREA does not Granger Cause SR_JAPAN & 415 & 2.20752 & 0.1113 \\
\hline SR_JAPAN does not Granger Cause SR_SOUTH_KOREA & & 1437 & 0.4016 \\
\hline SR_SOUTH_KOREA does not Granger Cause SR_SINGAPORE & 415 & 0.38085 & 0.6835 \\
\hline SR_SINGAPORE does not Granger Cause SR_SOUTH_KOREA & & 0.95028 & 0.3875 \\
\hline Null Hypotheses: & Obs & F-Statistic & Prob. \\
\hline BY_SINGAPORE does not Granger Cause BY_SOUTH_KOREA & 415 & 1.92257 & 0.1475 \\
\hline BY_SOUTH_KOREA does not Granger Cause BY_SINGAPORE & & 1.13428 & 0.3227 \\
\hline BY_JAPAN does not Granger Cause BY_SOUTH_KOREA & 415 & 1.42516 & 0.2417 \\
\hline BY_SOUTH_KOREA does not Granger Cause BY_JAPAN & & 3.56898 & $0.0291 * *$ \\
\hline BY_HONG_KONG does not Granger Cause BY_SOUTH_KOREA & 415 & 0.37428 & 0.6880 \\
\hline BY_SOUTH_KOREA does not Granger Cause BY_HONG_KONG & & 5.35871 & $0.0050 * * *$ \\
\hline BY_CHINA does not Granger Cause BY_SOUTH_KOREA & 415 & 456 & 0.0455 \\
\hline BY_SOUTH_KOREA does not Granger Cause BY_CHINA & & 7.01206 & $0.0010 * * *$ \\
\hline BY_JAPAN does not Granger Cause BY_SINGAPORE & 415 & 0.40499 & 0.6673 \\
\hline BY_SINGAPORE does not Granger Cause BY_JAPAN & & 0.75824 & 0.4691 \\
\hline BY_HONG_KONG does not Granger Cause BY_SINGAPORE & 415 & 1.00794 & 0.3659 \\
\hline BY_SINGAPORE does not Granger Cause BY_HONG_KONG & & 1.25113 & 0.2873 \\
\hline BY_CHINA does not Granger Cause BY_SINGAPORE & 415 & 0.24212 & 0.7851 \\
\hline BY_SINGAPORE does not Granger Cause BY_CHINA & & 0.91728 & 0.4004 \\
\hline BY_HONG_KONG does not Granger Cause BY_JAPAN & 415 & 0.66130 & 0.5167 \\
\hline BY_JAPAN does not Granger Cause BY_HONG_KONG & & 1.95844 & 0.1424 \\
\hline BY_CHINA does not Granger Cause BY_JAPAN & 415 & 0.07044 & 0.9320 \\
\hline BY_JAPAN does not Granger Cause BY_CHINA & & 0.07136 & 0.9311 \\
\hline BY_CHINA does not Granger Cause BY_HONG_KONG & 415 & 0.63241 & 0.5318 \\
\hline BY_HONG_KONG does not Granger Cause BY_CHINA & & 2.45792 & $0.0869 *$ \\
\hline
\end{tabular}

Note: * Sig. at level $10 \%$

** Sig. at level $5 \%$

*** Sig. at level $1 \%$ 
The last test to examine the financial market integration in Granger causality test. Based on the Table 6 can be seen that the null hypothesis states that bond yield does not cause a change in the stock return is rejected and accept the alternative hypothesis. Thus, it is proved that bond yield causes a change in the stock return with a significance level of 10\%. Table 6 of Pairwise Granger causality tests with the second null hypothesis confirm that there is no integration between the sample countries in Asia because the significant short-run dynamics or causality relationship of stock market (stock return) only exist in China-Hong Kong; Japan-China; China-Singapore; ChinaSouth Korea; Singapore-Hong Kong; South Korea-Hong Kong. While, the result of Granger causality tests between countries indicated that only four countries that integrated in a bond market in example South Korea-Japan; South Korea-Hong Kong; South Korea-China and Hong KongChina.

\section{RESEARCH CONCLUSION AND LIMITATION}

\subsection{Conclusion}

This study result shows that both stock and bond returns are co-integrated, shows as common stochastic trends. Stock market integration appears to be much stronger compared to the less developed. This result is very important for investors to assess potential gains from portfolio diversification. Financial policy-maker also get benefit from this research in managing market policies effectively and in handle contagion risks that might be caused by international shock transmissions.

\subsection{Limitation}

The study relies on widely cited empirical methods. However, adopting alternative specifications and also allowing time variant factors while examining inter-linkages between stock and bond markets seem to be appropriate for the robustness of the results. In addition, the data used in this study is weekly data, it may has a different results when using daily data.

\section{REFERENCES}

Balcilar, M., Kutanc, A. M., \& Yay, M. E. (2016). Financial Integration in Small Islands: The Case of Cyprus. International Review of Economics and Finance, 47, 201-219.

Berben, R., \& Jansen, W.J. (2005). Bond Market and Stock Market Integration in Europe (No. 06).

Buzelay, A. (2008). European Financial Integration and Global Financial Liberalization. Journal of Advances in Management Research, 5(1), 89-91.

Chai, H.-Y. \& Rhee, Y. (2005). Financial Integration and Financial Efficiency in East Asia. Paper presented at the Claremont-KIEP International Conference, 20 June (2005).

Deltuvaitè, V. (2015). CEECs' Financial Integration: Global or Regional? Evidence from Sovereign Bond Market. Procedia Economics and Finance, 24, 192-197.

Didier, T., Montanes, R. L., \& Schmukler, S. L. (2017). International Financial Integration of East Asia and Pacific. Journal of The Japanese and International Economies.

Flood, R. P. \& Rose, A.K. (2004). "Equity Integration in Times of Crisis", in Claudio, B., Hunter, W.C., Kaufman, G. and Tsatsaronis, K. (Eds), Market Discipline: The Evidence Across Countries and Industries, MIT Press, Cambridge, MA.

Kim, S.-J., Moshirian, F. \& Wu, E. (2006). Evolution of International Stock and Bond Market Integration: Influence of The European Monetary Union. Journal of Banking \& Finance, 30(5). 1507-1534. 
Kleimeier, S. \& Sander, H. (2000), Regionalisation versus Globalisation in European Financial Market Integration: Evidence from Cointegration Analysis. Journal of Banking \& Finance, 24(6).

Nguyen, T. D., \& Elisabeta, P. (2016). Financial Integration and Diversification Benefits: China and ASEAN4 Countries. Managerial Finance, 42(5).

Perera, A., \& Wickramanayake, J. (2012). Financial Integration in Selected South Asian Countries. South Asian Journal of Global Business Research, 1(2), 210-237.

Pyun, J. H., \& Jiyoun, A. (2016). Capital and Credit Market Integration and Real Economic Contagion During the Global Financial Crisis, Journal of International Money and Finance.

Rughoo, A. \& You, K. (2015). Asian Financial Integration-global or Regional-Evidence from Money and Bond Market. International Review of Financial Analysis.

Volosovych, V. (2011). Measuring Financial Maket Integratoin Over The Long Run-Is There a UShape. Journal of International Money and Finance, 30, 1535-1561.

$\mathrm{Yu}$, C. (2014). Evaluating International Financial Integration in a Center-Periphery Economy. Journal of International Economics: 1-16.

*) Fauziah, University of Malang, Malang, Indonesia (E-Mail: fauziah@unisma.ac.id) 